THE IMPLEMENTATION OF BLOOM'S REVISED TAXONOMY IN TEACHER'S QUESTIONS IN TEACHING ENGLISH AT SENIOR HIGH SCHOOL

\author{
AN ARTICLE
}

Submitted in Partial Fulfillment of the Requirements for the Degree of Sarjana Pendidikan

BY:

MAYA ANGGRIANI

Registration Number: 2161121024

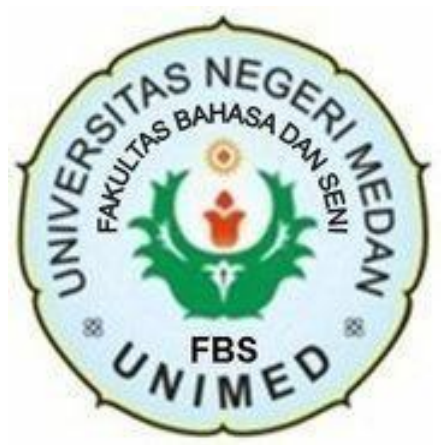

ENGLISH AND LITERATURE DEPARTMENT

FACULTY OF LANGUAGES AND ARTS

STATE UNIVERSITY OF MEDAN

2021 


\title{
THE IMPLEMENTATION OF BLOOM'S REVISED TAXONOMY IN TEACHER'S QUESTIONS IN TEACHING ENGLISH AT SENIOR HIGH SCHOOL
}

\author{
*Maya Anggriani \\ **Johannes Jefria Gultom
}

\begin{abstract}
The present study entitled “The Implementation of Bloom's Revised Taxonomy in Teacher's Questions in Teaching English at Senior High School" focuses on describing the categorization of teacher's questions according to the theory proposed by Wilen (1991) and Anderson and Krathwol (2000). The main purpose of the study is investigating and analyzing cognitive level of teacher' questions based on the mentioned theory, and additionally the technique of questioning used. The data were collected through the observation from the three lesson videos selected on Youtube and were transcribed. The researcher only focuses on collecting the teacher's question utterances from grade of X and XI senior high school in the topic of descriptive and biography text. The results showed that the teacher 1 used 8 techniques out of 9 techniques of questioning, teacher 2 and teacher 3 used 6 techniques of questioning. The three teachers similarly didn't use T9 technique, and frequently used T8 technique. There are 4 cognitive levels used by teacher 1 and teacher 2 those are remembering (C1), understanding (C2), analyzing (C4), and creating (C6). In the side of teacher 3 only used 2 cognitive levels in questioning the students, those are remembering $(\mathrm{C} 1)$ and understanding (C2). The three teachers frequently asked questions in the level of remembering (C1) respectively $69 \%$ from video 1 , video two is $43 \%$, and video 3 is $70 \%$.
\end{abstract}

Keywords: Teacher's Question, Bloom's Revised Taxonomy, Techniques of Questioning.

*Graduate Status

** Lecturer Status 


\section{INTRODUCTION}

Question is any sentence which has interrogative form or function (Cotton, 2012). Through question, someone can obtain a certain information in order to knowing something new or testing someone. In achieving the learning objectives there are several ways that teachers applying during the class. For example, through the teacher's question in order to analyze the students' comprehension and also spreading worksheet during the lesson.

The ministry of Education and Culture has been implemented a new curriculum named K13 and is still using until today. The curriculum is intended to increase the level of students' skills. Students are obligated to have thinking critically toward a case during the lesson and this will lead them become more active in the class. This new level of thinking called HOTS (High Order Thinking Skills). Teacher should have arranged their teaching material and even provide teaching media to help students train their critical thinking, also train themselves during classroom interaction by giving students question which can make students accustomed toward HOTS question, so that they will find it easy to answer questions during examination.

Nevertheless, nowadays teacher's perspective towards this HOTS level only focusing on their teaching material. In fact, they have neglected to implement it during the class through classroom interaction. In form of teacher's questions, students are able to train their perspective and opinion by facing a given case. Teacher would make students feel accustomed toward HOTS questions level by giving them question or case that classified as high level of cognitive. Most of teacher could been ignore this fact, but it is the best way to lead student develop their critical thinking rapidly.

This case can be seen as the following brief conversation during the lesson from teaching-learning video from Youtube:

$\mathrm{T}$ : Well, class, to check your understanding, please check your friend's grammatical errors in the dialogue. Is there any comment on your friend's dialogue? 
S: Me, mam. I think their dialogue is very good, because they have the expression of suggesting and offering.

T: Yes, Thank you.

Based on the brief dialogue above, it can be explained that the teacher is often asking the students in low cognitive level. The teacher just asking as such simple questions in order to check their skill of understanding which is to checking the grammatical error of their classmate's work. Although, the overall questions are still considered in LOTS, even in the section of exploring, associating, and communicating, which order the teacher to lead their students to think critically by throwing question in high cognitive level.

Thus the researcher would like to conduct a research and analyze the cognitive level of questions asked by the teacher and the technique of questioning used by the teacher as well.

\section{THEORITICAL FRAMEWORK}

\section{a. Teacher's Questions}

Questions often used in usual interaction with other people in order to open a conversation or to gain a certain information. According to Biber et.al (1999, p.211), questions are many times common in conversation, with average of one question per every 40 words in conversation, they are also commonly used in news and academic texts. Questions in the classroom are formed by teacher towards the students in order to gain information on how far do the students get the lesson, and students can throw questions towards teacher in purpose of clarifying a confusion or ensuring the instruction given by teacher.

Teacher's questions play some crucial part during the class when teacher is needed to clarify students' understanding through this activity. Not only should the teacher be responsive as listener, but he or she should also provide necessary instruction to students in how to develop and pose questions, how to engage with other when thinking aloud, and how to provide encouragement and support to students and peers as they grapple with ideas (Shaunessy, 2005, p. 8). Indeed, as teacher, they are responsible to provide some proper instructions and give logical 
questions to train students develop their critical thinking or share their thoughts to the other classmates.

\section{b. Technique of Questioning}

In delivering the questions, teacher unconsciously apply some techniques. In order to give the students the right moment in giving the questions and calculating the best question to the students, as proposed by Wilen (1991), there are nine techniques in throwing the questions, described as the following:

1. Plan key questions to provide lesson structure and direction

2. Phase questions clearly and specifically

3. Adapt questions to student ability level

4. Ask questions logically and sequentially.

5. Ask questions at a variety of levels

6. Follow up student responses.

7. Give students time to think when responding

8. Use questions that encourage wide student participation.

9. Encourage student questions.

Students will try to find the best answer toward the teacher's question, and allow them sharing their opinion towards a given case. Not only working individually, students can work together in order to find the answer, and it can train them their social psychology in building a good relationship to the other classmates even they can train their critical thinking.

\section{c. Cognitive Levels of Questions}

There are six cognitive process dimensions, those are remembering (retrieve relevant knowledge from long term memory), this stage including students in recognizing and recalling ability. The second cognitive level is understanding (construct meaning from instructional messages, including oral, written, and graphic communication), this stage required students in interpreting, exemplifying, classifying, summarizing, inferring, comparing, and explaining. The third stage called applying (carry out or use a procedure in a given situation), including executing and implementing.

The next stage of cognitive level is analyzing (break material into its constituent parts and determine how the parts relate to one another and to an 
overall structure or purpose), require students in differentiating, organizing, and attributing. The fifth stage is evaluating (make judgments based on criteria and standards), in here students needed to be able in checking and critiquing. The highest part of the cognitive level is creating (put elements together to form a coherent or functional whole; reorganize elements into a new pattern or structure. In this stage students are required to be able in generating, planning, and producing (Anderson and Krathwohl, 2001).

\section{RESEARCH METHODOLOGY}

In this research, the researcher applied a descriptive qualitative method. By using a descriptive qualitative method, the researcher has only collected, classified, and analyzed the data then draw the conclusions. In education, qualitative is frequently called naturalistic because the researcher frequents places where the events he or she is interested in naturally occur (Bogdan and Biklen, 1992).

The main data of this research are the entire teacher's questions during the class. The data has been collected from the teacher in the videos by transcript every conversation during the lesson and for the next step the researcher only gathered the teacher's utterances in form of questions related to the lesson as the data. The researcher was intended to collect the data from the uploaded videos in different senior high school and different teacher. The videos have been selected only from Grade X and XI as for the topic of teaching is about Long Functional Text.

While selecting the video, the researcher emphasized that the selected videos based on the most recent lesson video, and at least 2 years below before the pandemic of Covid19 which started to limited the classroom activities in the beginning of 2020. Therefore the researcher got three videos in total and based on the video, the teachers taught the lesson of Descriptive text and Biography text. The chosen videos uploaded by the teacher and the researcher would like to emphasize that the video was edited, it means that they are didn't recorded as full of 60 minutes of one meeting, and they were edited so only good things were recorded and uploaded. 
This research was conducted through the method of observation in order to collect the data. Gorman and Clayton define observation studies as those that involve the systematic recording of observable phenomena or behavior in a natural setting (Baker, 2006). The collected data has been analyzed in three steps, data condensation, data display, and conclusion. These steps are adapted from Miles, et.al (2014).

\section{THE DATA AND DATA ANALYSIS}

\subsection{The Data}

The researcher has selected three videos during teaching and learning uploaded on Youtube. These videos has been transcribed and from the transcription the researcher only used teacher's question utterances as the main data. There are also three different teachers, as well as they came from different school and different region in Indonesia. The topic of lesson has focused on long functional text from grade X AND XI.

The first video namely 'Video Pembelajaran Bahasa Inggris Materi Biography' and was uploaded by LD on her youtube channel and become the teacher in the video as well. And second, the uploaded video which has taken place in SMA N1 Langsa and tittled 'Video pembelajaran inquiry based learning (descriptive text) sman 1 langsa' and has got the permission to use as the data of this study from the uploader and also who has become the teacher in the video. And the last is the video uploaded by NR called 'Video Pembelajaran Biography'. These three selected videos have been transcribed and used as the data of the study. After the process of transcriptions, the teacher's question utterances have found.

\subsection{Data Analysis}

\section{a. Techniques of Questioning}

After collecting the data, coding the data, and the researcher reached to the classifying the data based on the theory used. The data will be described separately for each of the teachers. The complete explanations can be seen in the following section. 
Table 4.1 the distribution of teacher's questions based on technique of questioning

\begin{tabular}{|c|c|c|c|c|c|c|c|c|c|}
\hline \multirow{2}{*}{ Teacher } & \multicolumn{7}{|c|}{ Techniques of Questioning (Number of Question) } \\
\cline { 2 - 10 } & T1 & T2 & T3 & T4 & T5 & T6 & T7 & T8 & T9 \\
Teacher & 1 & 9 & 2 & 7 & 2 & 4 & 1 & 13 & - \\
\hline Teacher & 1 & 2 & - & - & 2 & 1 & 2 & 4 & - \\
2 & & & & & & & & & \\
\hline Teacher & 1 & 5 & 1 & 1 & - & - & 1 & 4 & - \\
3 & & & & & & & & & \\
\hline
\end{tabular}

\section{Plan key questions to provide lesson structure and direction (T1)}

Based on the data showed before, for this technique, the three teachers similarly used only one question during the lesson. In video 1 , the percentage can be presented as much of $3.5 \%$, in the video 2 the percentage appear up to $14 \%$, and for the third video got $12.5 \%$ of all questions during the lesson.

In the three videos, the first category of technique of questioning can be seen as the following questions:

-What are his achievements?

-Who wants to tell what is recount text, from your experience maybe?

-And where was he born?

Here the teacher asked students after hearing their response from the previous question spontaneously. It was obviously because the questions stated related to the same topic as the previous one.

\section{Phase questions clearly and specifically (T2)}

In the video 1, there are 9 questions out of 29 questions during the class, and it took $31 \%$ in percentage. While, in video 2 got $28.5 \%$ and from video 3 the percentage is $62.5 \%$. 
-'Born' present or past tense?

-What picture is this?

-From the script, you know that someone we choose to make biography text is?

Some example of questions from the second category can be seen above.

These questions stated clearly and had the obvious answer for students to response.

\section{Adapt questions to student ability level (T3)}

In order to use this technique in questioning the students, the teacher have to phrase questions in natural, simple language, adjusting vocabulary and sentence structure to studentse language and conceptual levels. Based on the data, it shows that video 1 got $7 \%$ from the entire questions during the lesson did not found in video 2 , and the last, $12.5 \%$ during the class in video 3 .

For the third category that required the teacher to phrase question in natural, simple language, adjusting vocabulary and sentence structure to students' language and conceptual levels. The example can be seen as following:

-What are the examples of them?

-Do you understand about the generic structure?

\section{Ask questions logically and sequentially (T4)}

The teacher required to give students question by considering the previous one. They have to ask student while having the same topic as the previous question had and the teacher should avoid such random question. In video 1, the teacher used this technique as the amount of $24 \%$ during the class. While video 2 , the teacher didn't use the technique, and last from video 3, it got $12.5 \%$. From the three videos, the used of the technique mentioned below:

-How about the reorientation of biography?

-What is it?

The two questions showed the teacher asked students sequentially based from the previous questions.

\section{Ask questions at a variety of levels (T5)}

There are 2 questions using this technique in video 1 as well as in video 2, each of them got percentage of $7 \%$ and $28.5 \%$, while in video 3 , the teacher did not used this technique. In this technique the teacher ought to give question where the student could train their creative and critical thinking. Among the three videos, 
only the teacher in video 1 and 2 applied this technique, and the questions appeared as below:

-Well, and then what is the content of the biography?

-Why do we choose historical places?

\section{Follow up student responses (T6)}

The technique needs the teacher to encourage students to clarify initial response, expand their response, for example "what are some alternatives?". From the data found $13.8 \%$ in video 1 , and as for video 2 , it took the percentage of $14 \%$, then in video 3 the technique could not found. From the following example of the used of this technique, the researcher could explain that by applying this technique means that teacher must encourages student to develop their answer and having a further explanation.

-The purpose of the writer is to?

-Where is it?

\section{Give students time to think when responding (T7)}

The three teachers in the videos used this technique in their class, 2 questions with the percentage was $7 \%$ in video 1 , also 2 questions from video 2 appear as percentage of $28.5 \%$, and 1 question in video 3 with the percentage took $12.5 \%$. While giving a question, sometimes the teacher might allow students to think before they could answer in more satisfying results. Practically, this technique can be seen in the following questions based on the three videos.

-How about the reorientation of biography?

-Who wants to summarize about our lesson today?

-What is our lesson in the last meeting?

\section{Use questions that encourage wide student participation (T8)}

It seemed this technique dominantly used during the class in the video 1, 2, and 3. That got $44 \%$ of questions given by the teacher used this technique in the video 1 , and $57 \%$ of questions used this technique for video 2 , and the last in amount of $50 \%$ of questions in video 3. The technique used by the three teachers in the videos when giving the questions during the class. Based on the data transcriptions, here some example took from the three videos: 
-The end of the story? Is that true?

-Did you know about Balai Juang?

-Any question about Abraham Lincoln?

\section{Encourage student questions(T9)}

Based on the data showed before, this technique of questioning which is applied by giving students opportunities to formulate questions and carry out follow-up investigations if interest, this technique could not be found in the three videos`. This technique showed that the teacher is a key in order to make students curious about the lesson. So, by giving question, teacher triggered students in asking more about the topic. And unfortunately, this technique did not found in the three videos.

\section{b. Cognitive Level of Question}

Table 4.3 the distribution of teacher's questions based on cognitive level

\begin{tabular}{|c|c|c|c|}
\hline Cognitive level & Video 1 & Video 2 & Video 3 \\
\hline C1 & 20 & 3 & 7 \\
\hline C2 & 5 & 2 & 3 \\
\hline C3 & - & - & - \\
\hline C4 & 3 & 1 & - \\
\hline C5 & - & - & - \\
\hline C6 & 1 & 46 Questions \\
\hline Total & &
\end{tabular}

\section{Lower Order Thinking Skills (C1, C2, C3)}

From the data showed, in video 1, there are 20 out of 29 questions applied during the class and can be seen as percentage of $69 \%$. In turn for the second cognitive level in Bloom's revised taxonomy, understanding, got the percentage of $28 \%$ during the lesson, and last, there were any applying type of question found.

In video 2, there were $43 \%$ from 7 questions categorized as remembering level, amount of $29 \%$ typical question in which the teacher usually asked students 
to indicate or identify something, this cognitive level called understanding, and there were not found for the third category of applying in the video 2 .

And for the last video, there found 2 categories in lower order thinking skills, remembering and understanding, with the percentage was $70 \%$ and $30 \%$, also the teacher in this video did not asked such practical questions or to interpret something.

In remembering, the teacher usually referred a question where the student needed to memorize or recognize from the existed answer based on the material showed. Here appeared some of example of question indicated as remembering level:

-In the biography, there are only three generic structures, what are they?

-Did you know about Balai Juang?

-When was he born?

The second cognitive level of questioning type called understanding coding as $\mathrm{C} 2$. In understanding, the content of question required the student to classify, identify, or indicate based on the topic being questioned. From the data, here the example of questions indicated as understanding level:

-Born' present or past tense?

-Who wants to summarize about our lesson today?

-Okay, between Abraham Lincoln and Ki Hajar Dewantara, who was born first?

From the three videos there were not found,,applyinge. In applying, the teacher gives question that needed students to apply, interpret or practice in order to response to the question.

\section{High Order Thinking Skills (C4, C5, C6)}

Based on the data, there were two categories out of three that applied in the video 1, it was in the level of analyzing in percentage of $10 \%$ and creating got the percentage of $3 \%$, in video 2 there were 2 categories applied, analyzing and creating, got the same percentage in amount of $14 \%$. And the last lesson video, there were not found any high order level questions during the class.

In analyzing cognitive level, the examples can be found in video 1 and 2, while in video 3 got none. In analyzing, usually the teacher used it to ask student 
in form of analyzing, differentiating, or comparing. Based on the data, the form of question can be seen below:

-Well, and then what is the content of the biography?

-Why do we choose historical places?

The fifth cognitive level of questions is evaluating where students have to response in way of choosing, evaluating, or judging from the topic of questions given. The researcher could not found any questions indicated as this cognitive level in the collected data.

The last classification of questions based on cognitive level is creating and the highest level in which the students ought to create or make a product in response. From the data, only in video 1 and 2 found this type of question gave by the teacher, and each video has one question as appeared in the following:

-What are the examples of them?

-Who wants to tell what is recount text, from your experience maybe?

\section{CONCLUSIONS AND SUGGESTIONS}

\section{a. Conclusions}

Based on the data and data analysis in the previous section, it can be concluded as the following:

1. The teacher in video 1 used eight out of nine techniques of questioning, the only technique did not apply by the teacher was encourage student question technique. The dominantly used technique of questioning number 8 , coding as $\mathrm{T} 8$ or use questions that encourage wide student participation as well as teacher in video 2. But, the researcher found that the teacher in video 2 did not apply three techniques of questioning, those are symbolized as T3, T4, T9. In other side, teacher in video 3 dominantly used technique number 2 , symbolize as T2 or phase questions clearly and specifically, while used seven questions and did not used technique number 5 and 9. In addition, based on the data collected the researcher concluded that the three teachers did not apply technique number 9 (encourage student questions) during the class and also there sometimes the teachers combined two techniques in questioning within one question. 
2. There found four cognitive levels among six detected during the class in video 1, those cognitive level were remembering, understanding, analyzing, and creating. The most dominant appeared was remembering level got twenty questions out of twenty nine with the percentage of $69 \%$. Turned to the next lesson video 2, the teacher was found in not using two cognitive levels those were applying and evaluating, and was dominantly give questions in remembering level with the percentage of $43 \%$. And the teacher in the last lesson video only used two cognitive levels for her entire questions during the class, those were remembering and understanding level, which appeared dominantly for remembering took $70 \%$.

\section{b. Suggestions}

Based on the conclusion explained above, the researcher proposed suggestions as for the English teacher and as well as for the next researcher who study the same topic as the present study:

1. The teacher supposed to give the different level of questions in order to train the creative and critical thinking of students, and also highly recommended to give at the higher level in the middle of main activity in stage of classroom. Give student at variety of technique would also increase their curiosity to the topic of lesson and eventually make the students more active during the class. The teacher could give some questions that make students wants to know more and at the end brave

2. The next researcher who wants to analyze the similar topic suggested to engage more participant in their study as well as they can specified to focused on study the appropriate technique along with the cognitive levels used in questioning students. They can also use another topic of study such as for short functional text, or using the other theories to add up the variety of study as the references.

\section{REFERENCES}

Anderson, L.W., and D.R. Krathwohl. (2001). A Taxonomy for Learning, Teaching, and Assessing. New York: Longman 
Bogdan, R.C., and S.K. Biklen (1992). Qualitative Research for Education. Boston: Pearson

Biber, D., S. Johansson., and G. Leech. (1999). Grammar of Spoken and Written English. Edinburgh: Longman

Bogdan, R.C., and S.K. Biklen (1992). Qualitative Research for Education. Boston: Pearson

Cotton, K. (2012). Classroom Questioning. School improvement series, 3.

Miles, M.B., A. M. Huberman., and J. Saldana. (2014). Qualitative Data Analysis: A Methods Sourcebook. Los Angeles: Sage

Shaunessy, E. (2005). Questioning Strategies for Teaching the Gifted. Texas: Prufrock Press, Inc.

Wilen, W.W. (1991). Questioning Skills for Teachers. Eric: National Education Association 